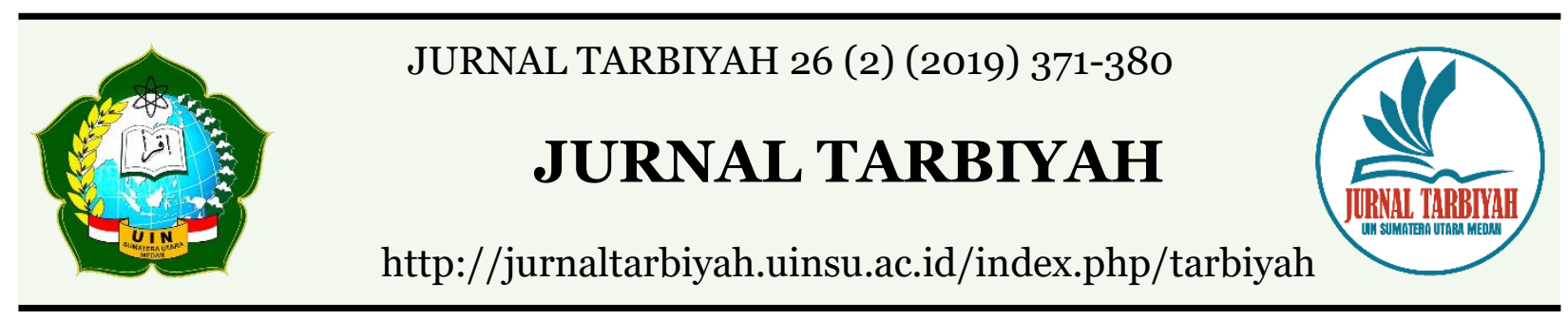

\title{
SYMBOLIC RESISTANCE OF ACEHNESE STUDENTS AGAINST NATIONAL NARCOTICS AGENCY HEGEMONY ON DRUG ERADICATION
}

\author{
Mohd. Nasir'1, Muhaini², Muhammad Mukhlis3 \\ 1,2,3 State Institute for Islamic Studies, Langsa, Indonesia \\ Email: kiwarikiwa@gmail.com
}

DOI : 10.30829/tar.v26i2.558

Accepted: September 29th, 2019. Approved: December 19th, 2019. Published: December 25th, 2019

\begin{abstract}
This study will describe the form of symbolic resistance of Acehnese students to drug eradication and photograph the forms of hegemony represented by the NNA Aceh in eradicating drugs for students in Aceh using the symbolic resistance theory of James C. Scott and Gramsci's hegemony. This research explored information through informants by conducting in-dept interviews, participant observation and documentation. This study found that the presence of students carrying symbolic resistance to drug eradication carried out by the National Narcotics Agency in the form of feeling uncomfortable, rejection body language, pouting officers and looking for excuses when counseling was conducted. This symbolic resistance emerged as a reaction to hegemony in various forms, namely dissemination, anti-drug volunteers, monday national flag ceremony, urine tests, seminar, DAPEICP curriculum and MoU.
\end{abstract}

Keywords: Symbolic Resistance, Drug Eradication 
Mohd. Nasir, Muhaini, Muhammad Mukhlis / JURNAL TARBIYAH 26 (2) (2019) 371-380

\section{INTRODUCTION}

Drug abuse continues to occur in various parts of the world (UNODC, 2019). In terms of the prevalence of drug users every year, Indonesia no exception, also faces serious threats. One of Indonesia's province, the Province of Aceh, which holds the Mecca portico and a "Shari'a country", is also affected by the drug. Several drug cases in Indonesia occur among Acehnese provincial students especially in Langsa City (Prohaba, 2017; Sindonews, 2017), both in the case of users, dealers and even as large international ports (Harahap et al., 2012;). This drug abuse affected all ages, be it an adults, teens, as well as children (National Narcotic Agent, 2014).

Indonesia's policies and strategies in tackling drug abuse continue to be carried out by National Narcotics Agent (NNA). The NNA conducted drug eradication in various forms of activities. The researchers found that the forms of relation between the ruling elite- the NNA with the community such as students in Aceh Province - were not monotonous in a single pattern of relations. There are various patterns of relations carried out by the NNA in an effort to eradicate drugs (Helviza et al., 2016). NNA banners are installed neatly on the side of the road, even with large quantities of billboards, this can be seen on the main streets of Aceh province with various editors, for example; Narcotics are our enemies, Avoid Consuming Drugs, Drugs are the Same as Hell, It's Time to be Free from Drugs, Healthy Generations Without Drugs, Arrested in Jail or Die in Hell, Drugs are Faceless Invaders, and so forth. Those kinds of banners are also can be seen at schools; Stop Drug Abuse, We Fight for Drugs, Drugs are our Enemies, there are also signpots of cooperation between schools and NNA related to drug abuse. Other forms are also carried out through student programs as anti-drug ambassadors; NNA-Built Schools for Drug Abuse Prevention, Eradication and Illicit Circulation Programs (DAPEICP), including gathering, campaigns and counseling.

Even though it was so intense and varied in the pattern of eradicating drugs, there were still many students who rejected this pattern of relations. Among the refusals that occurred were, for example, Matang Seulimeng village in Langsa cit. Based on the result of observation on Thursday, June $29^{\text {th }}, 2019$ in Matang Seulimeng Village of Langsa City, there was a teenager basically as a drug abuser. When the NNA carried out socialization in the village, the teenager was absent since he known that the socialization was carried out because he was a drug abuser. This kind of rejection was not only done by students or teenagers in the villages, but it also happened to students in schools both at junior and senior high schools. Although there was no direct resistance at school, a 
Mohd. Nasir, Muhaini, Muhammad Mukhlis / JURNAL TARBIYAH 26 (2) (2019) 371-380

symbolic rejection emerged through unfriendly attitudes when counseling was carried out by the NNA.

There are some studies related to narcotics prevention programme, such as Nurlaelah (2019) that examined various roles which were done by the NNA in preventing narcotics circulation in Makassar, Mukhlis (2013) which focused on on the patterns carried out by the NNA agents on prevention and abuse of narcotics and Herindrasti (2018) which focuse on the challenge faced by Indonesia in countermeasure of drug abuse. Despite this, very few research which focused on student's symbolic resistance toward narcotivs prevention programme.

This study used James C. Scott's symbolic theory of resistance (Scott, 2000) and Gramsci's hegemony (Patria \& Arief, 2003; Simon, 2014). In this case, the NNA as the upper class carried out acts of hegemony in an effort to eradicate drugs against the lower classes of society- Acehnese students. The NNA takes various forms of action in order to instill its class ideology. This ideological internalization was carried out by providing counseling, installing banners, billboards, gathering and so forth to strengthen the hegemony. This hegemony does not run smoothly, resistance arises from subordinate groups- Acehnese students. Resistance is used to find actions to reject or resist what Acehnese students have raised when responding to NNA actions in an effort to discipline drug abuse.

\section{RESEARCH METHOD}

This research is a qualitative research using phenomenological perspective (Nazir, 2004; Sutopo, 2006; Ruslan, 2008). In-depth interviews, participant observation and documention were used to collect the data. In-depth interviews were conducted with the head of NNA, the NNA employees, public figures, students, principals, teachers and parents. Observations were made on students who participated in drug counseling activities carried out by the NNA officers. The documentation was carried out to obtain each document that provides data on the forms of NNA hegemony and students symbolic resistance to the hegemony. The researchers collected information related to the data on the form of NNA counseling, symbolic resistance of students who were then selected, classified and interpreted (Miles \& Huberman, 1992). 
Mohd. Nasir, Muhaini, Muhammad Mukhlis / JURNAL TARBIYAH 26 (2) (2019) 371-380

\section{RESULT AND DISCUSSION}

\section{Form of Student Symbolic Resistance against Drug Eradication}

In general, resistance is understood as a resistance which indicates two opposing forces; the existence of power as something that is owned and the emergence of resistance as work to complain of external forces with other parties. It seems as if the two groups have no connection or relationship at all. Symbolic resistance of Acehnese students in the eradication of drugs by the NNA occurs in a process of inherent power relations. Resistance that is carried out by students is not meaningful to undermine each other or even destroy. It is a trait in the dynamics of drug eradication that is inherent in the process itself. Based on in-depth observations and interviews that the researchers conducted, a variety of symbolic resistances were practiced by students in the study locations, they are:

\section{Feeling uncomfortable}

Drug eradication through counseling and Monday flag ceremony is often carried out by the NNA. It seems that some students feel less comfortable following the Monday flag ceremony. The students seemed to behave discomfort during the ceremony and when counseling was carried out in the classroom or the hall. They could not stay longer in the classroom or in the hall and tried to find various reasons to leave the room where the counseling activities were held.

\section{Rejecting through body language}

Anti-drug parade involving students was also carried out by the NNA in an effort to eradicate drug abuse. Some students always seem to avoid taking part in these activities, although this rejection does not mean that they are indicated as users, but it could be due to the habit of lazy children and feeling tired when they are given additional tasks.

3. Saying they could not urinate

It happened when an officer would do a urine test, there was a student who refused to take a urine test. He said that he had just urinated and could no longer do that. Uniquely, a female officer asked the student if she could help him urinate. This moment made the public laughed, the student was ashamed and went to the toilet to do the work had been told.

\section{Pouting Officers}

Other symbolic resistance is played by students by pouting officers. The students gossiped the instructors with various unpleasant words secretly. Some of the students 
Mohd. Nasir, Muhaini, Muhammad Mukhlis / JURNAL TARBIYAH 26 (2) (2019) 371-380

said, "why they take care of other people, why don't they take care of themselves and their family. Wasting time taking care other people, but their family member was also a user".

\section{The Form of the Aceh NNA Hegemony towards Drug Abuse among Students}

Hegemony is a mastery effort by instilling ideology to dominate the class of society or grassroots, therefore, it is not seem as a treatment aimed at the enemy but rather the treatment of its allies. "Intellectual and moral" leadership of the NNA for these students can occur due to voluntary agreement from the schools. Principals and teachers agreed to the presence of the NNA in schools as a mandatory holder of eradicating drug abuse. The NNA, representing the government, has succeded in convincing the school to instill an understanding of the dangers of drug abuse and its eradication efforts among students.

Various forms of hegemony are as follow:

\section{Dissemination}

Dissemination activities carried out by the Langsa City NNA touched all elements of community, be it the public, government and private education institutions as well as students. Dissemination activities carried out by the NNA for the students at schools with the following stages; (1) informing the school about dissemination activities, (2) the school responded on the activities, (3) dissemination activities are carried out.

The schools provided the venue for the dissemination activities. The activities carried out by the NNA were not attended by all students in the class, but only represented by student representatives due to the limited place of dissemination. One of the Vice Principals stated that the dissemination activities in MAN 1 (State Madrasah) Islamic High School) Langsa were carried out at the school hall which was limited only for student representatives of each class. It is done to avoid disturbances of teaching and learning process in school. The student representatives were those who are considered capable of being represented by the NNA itself to inform and remind their classmates of the knowledge that had been learned from the dissemination activities.

Moreover, the students who were asked to attend the dissemination activities carried out by the NNA were also all members of intra-school students organization and alleged suspects of drug abuse as well as students who acted as anti-drug volunteers in SMA Negeri 1 Seruway. Dissemination activities are not only carried out during intracurricular occasions, but also in various extracurricular activities such as when the 
Mohd. Nasir, Muhaini, Muhammad Mukhlis / JURNAL TARBIYAH 26 (2) (2019) 371-380

school orientation is introduced. There are schools that invite the NNA to be a speaker in the orientation activities.

\section{Anti-drug Volunteers/Drug Activist}

The process of selecting activists is basically carried out through tests conducted by the NNA when disseminating information to schools. Students who are considered capable of answering the questions given by the NNA will be appointed as activists. In this case, SMA Negeri Seruway has another term which is called as an ambassador. This ambassador is a cadre who has been trained by the NNA and consisted of five students. The five ambassadors are considered as leaders and there are other students who become volunteers and actors. The volunteers work based on an order of the ambassadors. Five of them along with two school officers namely the principal and vice principal act as the coach of intra-school students organization were registered to NNA to be legalized and it applies nationally. Before conducting activities in Langsa, both NNA and school built networks and provided assistance to work and being facilitated with volunteer guidebook which contained the materials given throughout Indonesia. The volunteers were registered nationally based on the book.

\section{Monday National Flag Ceremony}

In addition to dissemination and the formation of volunteers, Monday National Flag Ceremony is a form of NNA dominance. These flag ceremony activities are routine activities carried out by the NNA and they have been scheduled at every school. The schedules could be requested by the NNA to the schools. However, the schools might also invite the NNA to disseminate information on drug abuse. The dissemination activities carried out though Monday National Flag Ceremony were attended by all students and teachers at the school. The NNA officer will act as a speaker of the ceremony to disseminate information and provide counseling to the students.

\section{Urine Test}

The urine test is also one form of hegemony carried out by the NNA, urine tests conducted by the NNA to the students are aimed at finding out which students are allegedly consumed the drug. The implementation of the urine test is carried out by the NNA in collaboration with the school. This test can be done after the dissemination activities or by arranging a suitable schedule. Nevertheless, not all students performed urine tests due to the limited funds owned by the NNA. Steps taken to carry out urine test in the school were firstly, the NNA sent a letter to the school to notify that a urine test would be held at the school. Secondly, drug activists carried out the urine test 
Mohd. Nasir, Muhaini, Muhammad Mukhlis / JURNAL TARBIYAH 26 (2) (2019) 371-380

secretly without knowing by the students who would be tested for urine, this was done to prevent the students who wanted to avoid this urine test. The students who selected to be tested were those who ellegedly indicated by drug abuse, the selection process was carried out by the school. Then the process of urine test is carried out by asking students - one by one and mostly dominated by male students - to enter a bathroom.

The door of the bathroom had to be opened to avoid cheating done by the students, it was also controlled by the NNA officers and assisted by the school both from the teachers and anti-drug volunteers from the school. The announcement of urine test results will not be exposed by the NNA, they only informed the school. It was done to keep the privacy of the school and students. In addition, if the results indicated that the students consumed the drug, they would be diagnosed to find out whether they were drug user or due to medicines and food factors. If it is proven that the students consumed the drug, they would be taken to a rehabilitation clinic.

5. Seminar

Another form of hegemony based on researchers' observations was through seminar activities. This seminar for students is conducted outside the schools. the procedures carried out in this seminar are the City or District NNA writes the schools in order to send their representatives to attend the seminar on drug abuse among students, then the schools responded and sent representatives to participate in the seminar. The seminar activities carried out by the NNA are expected to make the students to be able to postively prevent and avoid the danger of drug abuse. These activities were carried out from morning to evening. It was not carried out in the schools, but it was carried out at Harmoni Hotel which was attended by the reprentatives sent from each schools.

Students who take part in the seminar are students who have been selected as activists. In this seminar, those students are taught about the materials on the dangers of drug abuses. After the seminar finished, the students were given transport allowance by the NNA. Various materials were presented in this seminar, most of the materials were presented in details. Besides learning the topics presented by the NNA officers, the students also learning by playing games to reduce the participants' boredom. Students learned how to disseminate information in school. For instance, we can explain kinds of drugs to other students, the materials presented almost the same with the materials taught at school, but it is taught in very details. Besides that, students could also make new friends and had new experiences and share many life stories. Besides presenting 
Mohd. Nasir, Muhaini, Muhammad Mukhlis / JURNAL TARBIYAH 26 (2) (2019) 371-380

detail materials, the participants were also given tool kits and pins for national registration and pocket money.

5. DAPEICP Curriculum (Drug Abuse Prevention, Eradication, and Illicit Circulation Programs' Curriculum)

The NNA hegemony is not only limited to dissemination activities, anti-drug volunteers, seminars, Monday National Flag Ceremony and urine tests, but also through DAPEICP curriculum activities. It is hoped that students can get information-every students in each school subjects-on the dangers of drug abuse. This DAPEICP curriculum does not mean that there will be a subject on the DAPEICP, but its aim is to integrate the DAPEICP in every school subject. NNA invited the school principals in Langsa to attend a workshop. Then, the principals can share the infomation to the teachers. These teachers will inform- for example during a teaching and learning process of Religous subject- about the deeds that can be done or forbidden in Islam. In this case, the teachers can relate the subject to messages stipulated on the DAPEICP. Another example is a subject on Natural Sciences. The teachers can relate the messages in the DAPEICP to the brain. The teachers can explain several causes that damage the brain, one of them is drug. This is how the teachers can develop the messages stipulated in the DAPEICP.

Based on the interview data, all of the DAPEICP activities in each lesson plan taught by all subject teachers. The NNA together with the teachers made a lesson plan so that each subject would be integrated with the DAPEICP. This can actually be done not only for a certain subject, but also for all subjects. This program has been implemented in high schools, and this year we would propose this program to junior high school. The DAPEICP curriculum is intended to integrate each subject presented by the teachers in which they will inform about the dangers of drug abuse. The messages on DAPEICP will be included in every lesson plan and it must be correspond to the subject when presenting the drug abuses information.

7. MoU

The MoU or so called Memorandum of Understanding can be understood as a document that provides an explanation of various agreements between two parties. The $\mathrm{MoU}$ aims to ensure the agreements between the two parties in various fileds. According to the interview data, the NNA carried out MoU in the field of education, such as the Education and Culture Office and Ministry of Religious Affairs to expedite the DAPEICP activities into curriculum. 
Mohd. Nasir, Muhaini, Muhammad Mukhlis / JURNAL TARBIYAH 26 (2) (2019) 371-380

\section{CONCLUSION}

The resistance carried out by the students in general is symbolic or closed in the form of showing an attitude of feeling uncomfortable, rejecting by body language, pouting officers and looking for excuces when couseling in conducted. This symbolic resistance emerged as a reaction to hegemony in various forms, namely; dissemination, anti-drug volunteers, monday national flag ceremony, urine tests, seminar, DAPEICP curriculum and MoU.

\section{REFERENCES}

National Narcotics Agent (NNA). (2018). Badan Narkotika Nasional Republik Indonesia. Online. (http://www/bnn.go.id/). Accessed on 2019, Dec $3^{\text {rd }}$.

Harahap, I.M, Perngmark, P. \& Chanchong, W. (2012). Substance Use among Muslim Students in Aceh, Indonesia. Nurse Media Journal of Nursing. Vol. 2(2): 421436.

Helviza, I., Mukmin, Z. \& Amirullah. (2016). Kendala-Kendala Badan Narkotika Nasional (BNN) dalam Penanggulangan Penyalahgunaan Narkotika di Kota Banda Aceh. Jurnal Ilmiah Mahasiswa Pendidikan Kewarganegaraan Unsyiah. Vol. 1(1): 128-146.

Herindrasti, V.L.S. (2018). Drug-free ASEAN 2025: Tantangan Indonesia dalam Penanggulangan Penyalahgunaan Narkoba. Jurnal Hubungan Internasional. Vol.7(1): 19-23.

Miles, M.B.A \& Huberman, M. (1992). Analisis Data Kualitatif: Buku Sumber Tentang Metode-Metode Baru. (Rohidi, T.R., Translation). Jakarta: UI Press.

Mukhlis, M. (2013). Pola Komunikasi Islam Penyuluh dalam Pencegahan dan Pemberantasan Bahaya Penyalahgunaan Narkoba di Kalangan Remaja Kota Langsa. (Tesis: Program Pascasarjana IAIN Sumut)

Nazir, M. (2004). Metode Penelitian. Jakarta: Ghalia Indonesia.

Nurlaelah, Harakan, A. \& Mone, A. (2019). Strategi Badan Narkotika Nasional (BNN) dalam Mencegah Peredaran Narkotika di Kota Makassar. Journal of Goverment and Political Studies, Vol. 2(1): 24-31.

Patria, N, \& Arief, A. (2003). Antonio Gramsci: Negara dan Hegemoni. Yogyakarta: Pustaka Pelajar.

Pengungkapan Kasus Narkoba, (2017, April 1). Serambi Indonesia. 
Mohd. Nasir, Muhaini, Muhammad Mukhlis / JURNAL TARBIYAH 26 (2) (2019) 371-380

Prohaba. (2017, Oktober 2). Polisi Cokok Komplotan Pengedar Sabu di Kalangan Pelajar. Diakses di http://prohaba.co/m/index.php/2016/o7/19/polisi-cokokkom-plotan-pengedar-sabu-di-kalangan-pelajar.

Ruslan, R. (2008). Metode Penelitian Public Relations dan Komunikasi (Edisi 4). Jakarta: Raja Grafindo Persada.

Scott, J. (2000). Senjatanya Orang-orang Kalah. Jakarta: Yayasan Obor Indonesia.

Simon, R. (2014). Gagasan-Gagasan Politik Gramsci. (Kamdani dan Imam Baehagi, Translation). Yogyakarta: Pustaka Pelajar.

Sindonews. (2017, Oktober 22). Kecanduan Narkoba Sejak SMP Pelajar SMU Ini Jadi Bandar. Diakses dari https://daerah.sindonews.com/read/11243368/174/ kecanduan-narkoba-sejak-smp-pelajar-smu-ini-jadi-bandar-1468848987.

Sutopo. (2006). Metodologi Penelitian Kualitatif. Surakarta: UNS Press.

United Nations Office on Drugs and Crime (UNODC). (2019). World Drug Report 2019. Vienna: UNODC Research. 